\title{
CORPORATE SOCIAL RESPONSIBILITY IN EUROPEAN AND ASIAN COUNTRIES
}

\author{
Ruth Alas, Ülle Übius, Peeter Lorents, Erika Matsak
}

Estonian Business School, University of Tallinn

\section{A R T I C LE I N FO}

\section{Keywords :}

corporate social responsibility, China, Estonia, Finland, Slovakia and Japan

\author{
Kata Kunci : \\ Tanggung jawab social perusahaan, Cina, \\ Estonia, Finlandia, Slovakia dan Jepang
}

\begin{abstract}
The purpose is to study the two facets of corporate social responsibility (CSR) and their similarities and differences between European and Asian countries in different industries. A survey was conducted in Estonian, Chinese, Finnish, Slovakian and Japanese enterprises. Data about two facets of corporate social responsibility, three different branches and five different countries were compared by applying Lorents's metrics. The ordered pairs were created for each branch and country priorities separately. The distances between priorities were calculated. The total number of respondents was 4187. CSR is influenced by social and cultural environment and industry where the organisation operates. From two facets of CSR the firm respect the interests of agents is more connected with cultural backround than with economic development. The second facet of CSR - firm performance concerning social issue - is more connected with industry than culture. There could also be other factors like ethics, leadership, innovation influencing corporate social responsibility and its similarities and differences in different countries.
\end{abstract}

Tujuannya adalah untuk mempelajari dua aspek tanggung jawab sosial perusahaan (corporate social responsibility / CSR) dan persamaan serta perbedaan antara negara-negara Eropa dan Asia di berbagai industri.

Metodologi / pendekatan - Sebuah survei telah dilakukan di perusahaan Estonia, Cina, Finlandia, Slowakia dan Jepang. Data tentang dua aspek tanggung jawab sosial perusahaan, tiga cabang yang berbeda dan lima negara yang berbeda dibandingkan dengan menerapkan metrik Lorents. Pasangan yang dipesan dibuat untuk masing-masing prioritas cabang dan negara secara terpisah. Jarak antara prioritas dihitung. Jumlah responden adalah 4187.

Temuan - CSR dipengaruhi oleh lingkungan sosial, budaya dan industri tempat organisasi beroperasi. Dari dua aspek CSR, perusahaan menghormati kepentingan agen lebih terhubung dengan latar belakang budaya dibandingkan 
Corresponding author :

Ruth.Alas@ebs.ee dengan pembangunan ekonomi. Aspek kedua dari CSR kinerja perusahaan mengenai isu sosial - lebih berkaitan dengan industri daripada budaya.

Batasan / implikasi penelitian Ada juga faktor lain seperti etika, kepemimpinan, inovasi yang mempengaruhi tanggung jawab sosial perusahaan dan persamaan dan perbedaan di berbagai negara.

Implikasi Praktis - Tanggung jawab sosial perusahaan adalah faktor kunci keberhasilan dan oleh karena itu sangat penting untuk membandingkan berbagai negara - China, Jepang, Estonia, Slowakia dan Finlandia, terutama dengan negara yang memiliki kekuatan ekonomi terkemuka di dunia - China. Orisinalitas / nilai - Keaslian dalam makalah ini adalah analisisnya terhadap dua aspek tanggung jawab sosial perusahaan - kinerja perusahaan mengenai masalah sosial dan penghormatan perusahaan terhadap kepentingan agen di perusahaan Estonia, Cina, Finlandia, Slowakia dan Jepang dengan menggunakan metrik Lorents .

\section{Background}

\section{INTRODUCTION}

Previous studies have shown institutional impact on different processes and attitudes in organisations (Alas et al 2006; Alas 2006; Alas and Rees 2006; Tafel-Viia and Alas 2009; Alas et al 2009a; Alas et al 2009b; Alas and Edwards 2011). Cultural values influence leadership style (Alas and Tuulik 2007) and corporate social performance (Übius and Alas 2009). The development of corporate social responsibility (CSR) is connected with institutional development stage (Tafel and Alas 2007). Today, enterprises integrate social entrepreneurship into their core activities. They channel their research-and-development capabilities in the direction of socially innovative products and services (Schwab, 2008).

One of the most important challenges is acknowledging and appreciating cultural values and practices in different parts of the world. Experts agree that to succeed in global business, managers need the flexibility to respond positively and effectively to practices and values that may be drastically different from what they are accustomed to (House et al, 2004).

The paper starts with theoretical framework of the study by presenting a brief overview of the literature on this topic. This is followed by results of empirical study. A standardised corporate social responsibility questionnaire comprising 19 items developed by the Denki Ringo research group (Ishikawa et al, 2006) was used to explore two facets of corporate social responsibility. Questionnaire was administered in Estonian, Chinese, Finnish, Slovakian and Japanese electrical-electronic machine, retail and machine-building enterprises.

\section{THEORETICAL FRAMEWORK}

\section{Theories about Corporate Social Responsibility}

There are many different definitions of corporate social responsibility (CSR) although they have considerable common ground between them. Today leaders face a challenging task in attempting to apply societal ethical standards to responsible business practice (Morimoto et al., 2005). Nowadays corporate social 
responsibility is an integral part of the business vocabulary and is regarded as a crucially important issue in management (Cornelius et al., 2008; Humphreys and Brown, 2008).

Carroll (1991) four kinds of social responsibilities constitute total CSR: economic, legal, ethical and philanthropic. These four categories or components of CSR might be illustrated as a pyramid. Freeman (1994) stakeholder language has been widely adopted in practice and is being integrated into concepts of corporate responsibility/citizenship by scholars who recognize that it is through a company's decisions, actions and impacts on stakeholders and the natural environment that a company's corporate responsibility/citizenship is manifested.

Hillman and Keim (2001) state that it is critical to discriminate between stakeholder management CSR and social CSR. This is consistent with Baron's (2001) distinction between strategic and altruistic CSR. The authors concluded that stakeholder-oriented CSR was positively correlated with financial performance and social CSR was not.

There are more investment in companies that practice and report CSR (Sleeper et al., 2006). Corporate social responsibility forces a repositioning of strategies from being profit-driven organisations to organisations that are interested in the company's influence on social and environmental aspects (Quaak et al., 2007).

\section{The Firm's Performance Concerning Social Issues}

Sethi (1975) stated that social responsibility is prescriptive in nature. Epstein (1987) provided a definition of CSR in his quest to relate social responsibility, responsiveness and business ethics. Frederick (1960) states that social responsibility in the final analysis implies a public posture toward society's economic and human resources and a willingness to see that those resources are used for broad social ends. According to Drucker (1984) the proper social responsibility of business is to turn a social problem into economic opportunity.

The concept of a corporate social performance stream emerged in the 1990s (Wood, 1991). Waddock and Graves (1997) state that there is a positive relationship between a firm's social and financial performance. Orlitzky et al. (2003) state that there is strong empirical evidence supporting the positive link between social and financial performance.

Marcel van Marrewijk (2003) state that three dimensions of corporate action are covered by the concept of corporate social responsibility: economic, social and environmental management. Garriga and Mele' (2004) allocate theories of corporate social responsibility into four groups: instrumental, political, integral and ethical theories. These four groups could be taken as developmental stages of corporate social responsibility.

Alas and Tafel (2008) proposed the 4 stage model for analyzing CSR in a country in transition: (1) economic responsibility, (2) pressured or public social responsibility, (3) social responsiveness and (4) social issues management.

\section{The Firm's Respect for The Interests of Agents}

Stakeholder theory, popularized by Freeman (1984; 1994), essentially argues that a company's relationships with stakeholders is core to understanding how it operates and adds value as a business. Freeman (1994) argues that stakeholder language has been widely adopted in practice and is being integrated into concepts of corporate responsibility/citizenship by scholars who recognize that it is through a company's decisions, actions and impacts on stakeholders and the natural environment that a company's corporate responsibility/citizenship is manifested.

Corporate social responsibility is a concept where companies integrate social and environmental concerns in their business operations in order to fulfil accountability to their stakeholders (Tanimoto, Suzuki, 2005). When companies in different countries define their CSR policies they have to take into consideration cultural differences (Bird and Smucker, 2007).

The main research questions are: (1) is corporate social responsibility similar in electrical-electronic machine and machine-building enterprises and different in retail store enterprises; (2) are two facets of corporate social responsibility similar among Asian and European countries and different between Asian and European countries?

Estonia, Japan, China, Finland and Slovakia have different social, economic, political, historical and cultural environments. The author chose these countries for the empirical research because the sample enables us 
to compare countries with a similar cultural background (Estonia and Finland) or (Japan and China) with countries that have different cultural background (Japan and Slovakia) or (Estonia and China) etc.

Based on the relevant literature authors developed the following general propositions:

P1. Two facets of corporate social responsibility are similarly evaluated in electrical-electronic machine and machine-building enterprises and differently evaluated in retail store enterprises.

P2. Two facets of corporate social responsibility are similarly evaluated among Asian and European countries and differently evaluated between Asian and European countries.

\section{Empirical Study}

In order to investigate similarities and differences concerning the two facets of corporate social responsibility the empirical study was conducted by Denki Ringo research group. The authors of this article conducted survey in Estonia. The research was conducted with 623 respondents in Estonian enterprises, 1150 respondents in Chinese enterprises, 605 respondents in Slovakian enterprises, 239 respondents in Finnish enterprises and 1570 respondents in Japanese enterprises. The companies were selected in a non-random manner, as the organisation registers do not have a solid basis for random sampling because only a fraction of the registered enterprises are active in Estonia, China, Japan, Finland and Slovakia. There were 6 enterprises from Estonia, 6 from China, 3 from Slovakia, 4 from Finland and 6 enterprises from Japan in the study. All together 25 enterprises. The total number of respondents was 4187.

\section{RESEARCH METHOD}

A standardised corporate social responsibility questionnaire comprising 19 items was developed by the Denki Ringo research group (Ishikawa et al, 2006) and translated from English into Estonian, Chinese, Finnish, Slovak and Japanese. The questions in the survey addressed 2 facets of corporate social responsibility - the firm's performance concerning social

issues (11 items) and the firm's respect for the interests of agents ( 8 items). These two facets of corporate social responsibility were chosen because they typify the essential character of CSR. The questionnaire was administered in Estonian, Chinese, Finnish, Slovakian and Japanese electrical-electronic machine, retail and machine-building enterprises. The data about the two facets of corporate social responsibility, three different branches and five different countries - Estonia, China, Slovakia, Finland and Japan - were compared by using Lorents's metrics.

\section{Choices and Applications of Metrics to Intepret Study Results}

Study results of value judgements compose of the list of estimated things and their corresponding numeric estimations as a rule. It is possible to compose orders that express importance, priority etc. of characteristical things for different respondents (or groups of respondents) originated from the values of numeric estimations.

Thereat often arises the following question among investigators: how similar or dissimilar are "pictures" formed by estimations of study results. Specification of following circumstances is needed to answer to this question (Lorents 2006):

How are these objects (for example aggregations composed of some elements in certain way) determined that similarity or dissimilarity should be identified?

How is determined identified similarity or on the contrary dissimilarity?

How is similarity or dissimilarity estimated (including: what is used as estimations and how are estimations attributed to estimated things)?

In this article answers to first question could be following:

In the first case observed as objects, which similarity or on the contrary -dissimilarity should be identified, aggregations of fixed number and located in the fixed way elements which elements are real numbers (representing some values). Thereat it is assumed, that the number and location of elements is fixed in the same 
way concerning all comparable aggregations (for example the third element is in all cases for the ethical values, but the fifth element is for the social values).

In the second case aggregations of fixed location elements are observed. Thereat it is not assumed that the location of elements is the same concerning all comparable aggregations (for example Chinese youngsters` third element is ethical value, social values are on the contrary the seventh element; Turkish youngsters ethical values are a bit higher - namely the second element, third element for them is value related to lifestyle, social values are on the contrary the fifth element).

Subsequently we explain, how could we (originated from the answers given to the first question) determine similarity or on the contrary dissimilarity:

Concerning these kind of aggregations, which elements` number and location is fixed and the same for all observed aggregations and which elements are real numbers, it is not reasonable to use morfisms' (for example homomorphism or isomorphism) term, which is usually used for relational systems or for the identification of algebra similarity (Grätzer 2008, Lorents 2006). Rather it is reasonable to rely on $n$-dimensional real space Euclidean metric when we estimate the similarity (Deza, 2009). In this case we could handle comparable aggregations - for example $\mathrm{x}$ and $\mathrm{y}$ - according to $\mathrm{n}$-dimensional real space points. In this case we could use expressed number $\mathrm{d}(\mathrm{x}, \mathrm{y})$ of closeness or distance of corresponding points as the estimation of similarity or dissimilarity of the named aggregations, where

$\mathrm{d}(\mathrm{x}, \mathrm{y})=\left(\left(\mathrm{x}_{1}-\mathrm{y}_{1}\right)^{2}+\left(\mathrm{x}_{2}-\mathrm{y}_{2}\right)^{2}+\left(\mathrm{x}_{3}-\mathrm{y}_{3}\right)^{2}+\ldots+\left(\mathrm{x}_{\mathrm{n}}-\mathrm{y}_{\mathrm{n}}\right)^{2}\right)^{1 / 2}$.

Whereby: smaller is the number $\mathrm{d}(\mathrm{x}, \mathrm{y})$, more similar are the comparable aggregations $\mathrm{x}$ and $\mathrm{y}$ and on the contrary - bigger is the number $\mathrm{d}(\mathrm{x}, \mathrm{y})$, less dissimilar are $\mathrm{x}$ and $\mathrm{y}$ in this study.

In case of such aggregations the number of elements is final, but the location of elements may be not similar according to comparable aggregations, we should precise more to evaluate the similarity in order to make sure what is it, what similarity we wish to estimate. At this point we agree upon that in this case we wish to estimate the similarity of the order of the location of elements in comparable aggregations. Thereat we mean elements order when we are talking about the order of elements location. Order is represented by the order connection between (binary) the elements. From the number theory (which rely on ordered aggregations or mathematical systems theory) it is known that whatever binary connection is one certain amount composed by sorted pairs.

Thereafter if we wish to evaluate how similar or dissimilar are some (final) orders, then in turn we have to evaluate how similar or dissimilar are the amounts of corresponding ordered pairs. Last task is again reduced to the application of differentiations metrics of final aggregations (Marczewski, Steinhaus 1958; Lorents 2002; Jents 2004; Lorents 2007).

More precisely - if we mark some amounts $\mathrm{A}$ and $\mathrm{B}$ intersection or these common elements aggregation with the symbol $\mathrm{A} \cap \mathrm{B}$, we mark amounts $\mathrm{A}, \mathrm{B}$ and $\mathrm{A} \cap \mathrm{B}$ elements numbers with corresponding symbols $\mathrm{E}(\mathrm{A}), \mathrm{E}(\mathrm{B})$ and $E(A \cap B)$, then we can find the number $d(A, B)$ that expresses relative differentiation of these amounts by means of following formula:

$$
d(A, B)=[E(A)+E(B)-2 E(A \cap B)]:[E(A)+E(B)-E(A \cap B)]
$$

\section{RESULT AND DISCUSSION}

Our main purpose was to evaluate the similarities and differences in Estonia, Finland, Japan, China and Slovakian industries concerning the two facets of corporate social responsibility. The data about the two facets of corporate social responsibility, three different branches and five different countries - Estonia, China, Slovakia, Finland and Japan - were compared. 


\section{Corporate Social Responsibility in Three Branches}

Table 1 shows respondents opinions about the firm performance concerning social issues. The statements were rated highly in retail store enterprises $(\mathrm{m}=3.90, \mathrm{sd}=0.97)$ and electric-electronic machine enterprises $(\mathrm{m}=3.85, \mathrm{sd}=0.92)$. In machine-building enterprises statements were rated lower $(\mathrm{m}=3.60$, $\mathrm{sd}=1.03)$.

Table 2 shows respondents opinions about facet of corporate social responsibility - the firm respect the interests of agents. The statements were rated highly in retail store enterprises $(\mathrm{m}=3.60, \mathrm{sd}=1.14)$. Statements were rated a little bit lower in machine-building enterprises $(\mathrm{m}=3.56, \mathrm{sd}=1.05)$ and electricelectronic machine enterprises $(\mathrm{m}=3.53, \mathrm{sd}=1.03)$.

\section{Corporate Social Responsibility in Five Countries.}

Tables 3 and 4 show respondents opinions about CSR in five countries. In China the statements were rated highly in retail store enterprises - the firm performance concerning social issues $(\mathrm{m}=4.32, \mathrm{sd}=0.81)$ and the firm respect the interests of agents $(m=4.04$, $s d=0.91)$. Statements were rated lower in machinebuilding enterprises - the firm performance concerning social issues $(\mathrm{m}=4.06, \mathrm{sd}=1.05)$ and the firm respect the interests of agents $(\mathrm{m}=3.96, \mathrm{sd}=1.02)$ and electric-electronic machine enterprises - the firm performance concerning social issues $(\mathrm{m}=4.02, \mathrm{sd}=1.01)$ and the firm respect the interests of agents $(\mathrm{m}=3.87, \mathrm{sd}=0.95)$.

In Estonia the statements were rated highly concerning the facet of CSR - the firm performance concerning social issues in retail store enterprises $(\mathrm{m}=4.37, \mathrm{sd}=0.51)$ and in electric-electronic machine enterprises $(\mathrm{m}=4.10, \mathrm{sd}=0.89)$ and concerning the facet of CSR - the firm respect the interests of agents in electric-electronic machine enterprises $(\mathrm{m}=3.31, \mathrm{sd}=1.08)$ and in machine-building enterprises $(\mathrm{m}=3.22, \mathrm{sd}=0.99)$. Statements were rated lower concerning the facet of CSR - the firm performance concerning social issues in machine-building enterprises $(\mathrm{m}=3.36, \mathrm{sd}=0.77)$ and concerning the facet of CSR - the firm respect the interests of agents in retail store enterprises $(\mathrm{m}=3.16$, $\mathrm{sd}=0.63)$.

In Finland the statements were rated highly concerning the facet of CSR - the firm performance concerning social issues in electric-electronic machine enterprises $(\mathrm{m}=3.62, \mathrm{sd}=0.89)$ and in retail store enterprises $(\mathrm{m}=3.68, \mathrm{sd}=0.90)$ and concerning the facet of CSR - the firm respect the interests of agents in retail store enterprises $(\mathrm{m}=3.52$, $\mathrm{sd}=0.96)$.

Statements were rated lower concerning the facet of CSR - the firm respect the interests of agents in electricelectronic machine enterprises $(\mathrm{m}=3.32$, $\mathrm{sd}=0.99)$.

In Japan the statements were rated highly in electric-electronic machine enterprises concerning the facets of CSR - the firm performance concerning social issues $(m=3.79$, sd=0.80) and the firm respect the interests of agents $(\mathrm{m}=3.60, \mathrm{sd}=0.81)$. Statements were rated lower concerning the facet of CSR - the firm performance concerning social issues in machine-building enterprises $(\mathrm{m}=3.18, \mathrm{sd}=0.88)$ and in retail store enterprises $(\mathrm{m}=3.28, \mathrm{sd}=0.85)$ and concerning the facet of CSR - the firm respect the interests of agents in machine- building enterprises $(\mathrm{m}=3.15, \mathrm{sd}=0.83)$ and in retail store enterprises $(\mathrm{m}=3.28, \mathrm{sd}=0.91)$.

In Slovakia the statements were rated highly concerning the facets of CSR - the firm performance concerning social issues in machine-building enterprises $(\mathrm{m}=3.73, \mathrm{sd}=0.86)$ and retail store enterprises $(\mathrm{m}=3.86, \mathrm{sd}=1.05)$. Concerning the facets of CSR - the firm respect the interests of agents in machine-building enterprises $(\mathrm{m}=3.65, \mathrm{sd}=0.88)$ and retail store enterprises $(\mathrm{m}=3.86, \mathrm{sd}=1.01)$.

\section{Distances concerning CSR}

The ordered pairs were created for each branch priorities separately. The distance between priorities have been calculated by using Lorents's metrics.

\section{The firm performance concerning social issues in 3 industries.}

We compared priorities between machine-building industry, electric-electronic machine industry and retail store. In each industry it is possible to create 55 pairs. The most similar are machine- building industry and electric-electronic machine industry, they have 51 common pairs. 


\section{The firm respect the interests of agents in 3 industries.}

We compared priorities between machine-building industry, electric-electronic machine industry and retail store. In each industry it is possible to create 28 pairs. Equally similar are machine- building industry and electric-electronic machine industry, they have 24 common pairs and machine-building industry and retail store, they have 24 common pairs.

\section{The firm performance concerning social issues in 5 countries.}

We compared priorities between Estonian, Chinese, Slovakian and Japanese machine-building, electricelectronic machine and retail store industries concerning the facet of CSR - the firm performance concerning social issue. It is possible to create 55 pairs.

The most similar are Japanese and Slovakian retail store industries with 49 common pairs, followed by Estonian and Japanese machine-building industries and Estonian and Slovakian machine-building industries, both with 46 common pairs.

\section{The firm respect the interests of agents in 5 countries}

We compared priorities between Estonian, Chinese, Slovakian and Japanese machine-building, electricelectronic machine and retail store industries concerning the facet of CSR - the firm respect the interests of agents. It is possible to create 28 pairs.

The most similar are Chinese and Japanese machine-building industries (they have all 28 common pairs), Chinese and Japanese electric-electronic machine industries (they have 22 common pairs) and Japanese and Chinese retail store industries (they have 25 common pairs).

\section{CONCLUSION AND RECOMMENDATION}

The institutional environment of organisations influences how corporate social responsibility is evaluated. In different countries, corporate social responsibility as concepts are understood and applied differently in organisations.

The business world is becoming increasingly global. Corporations are facing increasingly global employees, customers, suppliers, competitors and creditors (House et al., 2004). Although successful management of the relationship with different stakeholders groups does not necessarily create short term profits, it may increase competitive advantage of the company in the long-term period (Jones, 1995). The results of this survey in Estonian, Chinese, Japanese, Finnish and Slovakian organisations reveal that there are similarities and differences concerning the two facets of corporate social responsibility. The propositions discussed at the beginning of the paper will now be re-evaluated.

$P 1$ postulated that two facets of corporate social responsibility are similarly evaluated in electrical-electronic machine and machine-building enterprises and differently evaluated in retail store enterprises. This proposition was partly supported by the findings. Concerning the facet of CSR - the firm performance concerning social issue - proposition was supported. The machine-building industry and electric-electronic machine industry have highest number of common pairs. These industries have less common pairs with retail industry. Concerning the facet of CSR - the firm respect the interests of agents - proposition was not supported. The number of common pairs is equally 24 for machine-building industry and electric-electronic machine industry and also for machine-building industry and retail store.

$\boldsymbol{P 2}$ postulated that two facets of corporate social responsibility are similarly evaluated among Asian and European countries and differently evaluated between Asian and European countries. This proposition was partly supported by the findings. The proposition was supported concerning the facet of CSR - the firm respect the interests of agents. The most similar are Chinese and Japanese machine-building industries with 28 common pairs, Japanese and Chinese retail store industries have 25 common pairs and Chinese and Japanese electricelectronic machine industries have 22 common pairs.

The proposition was not supported concerning the facet of CSR - the firm performance concerning social issue. The most similar are Japanese and Slovakian retail store industries with 49 common pairs, followed by Estonian and Japanese machine-building industries and Estonian and Slovakian machine-building industries, 
both with 46 common pairs.

To conclude, there are more similarities between culturally similar countries concerning the facet of CSR - the firm respect the interests of agents. Concerning the facet of CSR - the firm performance concerning social issue the most similar are machine-building industry and electric-electronic machine industry. Therefore from two facets of CSR the firm respect the interests of agents is more connected with cultural backround than with economic development. The second facet of CSR - firm performance concerning social issue - is more connected with industry than culture.

\section{REFERENCES}

Alas, R. (2006).Ethics in countries with different cultural dimensions. Journal of Business Ethics, Vol. 69 No. 3, pp. 237-247.

Alas, R. and Edwards, V. (2011). Work-related attitudes in Asia and Europe: Institutional approach, Engineering Economics, accepted.

Alas, R., Ennulo, J. and Türnpuu, L.(2006).Managerial values in the institutional context. Journal of Business Ethics, Vol. 65 No. 3, pp. 269-278.

Alas, R., Kraus, A., and Niglas, K. (2009a).Manufacturing Strategies and Choices in Cultural Contexts. Journal of Business Economics and Management, Vol. 10 No. 4, pp. 279-289. doi: Doi 10.3846/16111699.2009.10.279-289.

Alas, R. and Rees, C. J. (2006). Work-related Attitudes, Values and Radical Change in Post-Socialist Contexts: A Comparative Study. Journal of Business Ethics, Vol. 68 No. 2, pp. 181-189.

Alas, R., Sharifi, S. and Sun, W. (2009b).China and Estonia in Flux: Is this a valid basis for comparison of their approaches to change management?. Engineering Economics, Vol. 2 No. 62, pp. 18-27.

Alas, R. and Tafel, K. (2008).Conceptualizing the dynamics of social responsibility: Evidence from a case study of Estonia. Journal of Business Ethics, Vol. 81, pp. 371-385.

Baron, D. P. (2001). Private politics, corporate social responsibility and integrated strategy. Journal of Economics and Management Strategy, Vol. 10 No.1, pp. 7-45.

Bird F. and Smucker J. (2007). The Social Responsibilities of International Business Firms in Developing Areas. Journal of Business Ethics, Vol. 73, pp. 1-9.

Carroll, A. B. (1999). Corporate social responsibility: Evolution of a definitional construct. Business and Society, Vol. 38 No. 3, pp. 268-295.

Cornelius, N., Todres, M,. Janjuha-Jivraj, S,. Woods, A., Wallace, J. (2008). Corporate Social Responsibility and the Social Enterprise, Journal of Business Ethics, Vol. 81, pp. 355-370.

Deza E. and Deza M. M. (2009). Dictionary of distances, Elsevier, Amsterdam. 
Drucker, P F. (1984). The new meaning of corporate social responsibility. California Management Review, Vol. 26, pp. 53-63.

Epstein, E. M. (1987). The corporate social policy process: Beyond business ethics, corporate social responsibility, and corporate social responsiveness. California Management Review, Vol. 29, pp. 99-114.

Frederick, W. C. (1960). The growing concern over business responsibility. California Management Review, Vol. 2, pp. 54-61.

Freeman, R. E. (1984). Strategic Management: A Stakeholder Approach, Boston, Pitman.

Freeman, R. E. (1994). The Politics of Stakeholder Theory: Some Future Directions, Business Ethics Quarterly, Vol. 4, pp. 409-422.

Garriga, E., Melé, D. (2004). Corporate Social Responsibility Theories: Mapping the Territory. Journal of Business Ethics, Vol. 53 No. 1-2, pp. 51-71.

Grätzer G. (2008). Universal algebra, Second Edition, Springer.

Hillman, A. and Keim, G. (2001). Shareholder value, stakeholder management, and social issues: what's the bottom line? Strategic Management Journal, Vol. 22 No. 2, pp. 125-139.

House, R.J., Hanges P. J., Javidan M., Dorfman P. W., and Gupta V. (Eds) (2004). Culture, Leadership, and Organizations, The GLOBE Study of 62 Societies. Sage Publications, Inc.

Humphreys, M. and Brown, A. D. (2008). An Analysis of Corporate Social Responsibility at Credit Line: A Narrative Approach. Journal of Business Ethics, Vol. 80, pp. 403-418.

Ishikawa, A., Mako, C. and Warhurst, C. (2006). Work and Employee Representation: Workers, Firms and Union. Tokyo: Chuo University Press.

Jents M. (2004). Evaluation the difference of knowledge and concepts using the metrics of Lorents. Proceedings of the international conference on Artificial Intelligence, 2004, Las Vegas, USA, CSREA Press, Vol 1, pp. $338-341$.

Jones, T. M. (1995). Instrumental stakeholders theory: A synthesis of ethics and economics, Academy of Management Review, Vol. 20, pp. 404-438.

Lorents P. and Lorents D. (2002). Applying difference metrics of finite sets in diagnostics of systems with human participation. Proceedings of the International Conference on Artificial Intelligence, 2002, Las Vegas, USA, CSREA Press, Vol III, pp. 1297 - 1301.

Lorents P. (2006). Süsteemide maailm, Tartu University Press, Tartu.

Lorents, P. (2007). Denotations, Knowledge and Lies. Proceedings of the International Conference on 9 
Artificial Intelligence, 2007, Las Vegas, USA, CSREA Press, Vol. II, pp. 324-329.

Marcel van Marrewijk. (2003). Concepts and definitions of CSR and Corporate Sustainability: Between Agency and Communication. Journal of Business Ethics, Vol. 44 No. 2/3, pp. 95-105.

Marczewski E. and Steinhaus H. (1958). On a certain distance of sets and the corresponding distance of functions. Colloquium Mathematicum. Vol. VI, pp. 319 - 327.

Morimoto, R., Ash, J. and Hope, C. (2005). Corporate Social Responsibility Audit: From Theory to Practice. Journal of Business Ethics, Vol. 63, pp. 315-325.

Orlitzky, M., Schmidt, F. and Rynes, S. (2003). Corporate social and financial performance: a metaanalysis. Organisation Studies, Vol. 24 No. 3, pp. 403-441.

Quaak, L., Aalbers, T. and Goedee, J. (2007). Transparency of corporate social responsibility in Dutch Breweries. Journal of Business Ethics, Vol. 76, pp. 293-308.

Schwab, K. (2008). Global Corporate Citizenship. Foreign Affairs, Vol. 87 No.1, pp. 107-118.

Sethi, S. P. (1975). Dimensions of corporate social performance: An analytic framework. California Management Review, Vol. 17, pp. 58-64.

Sleeper, B. J., Schneider, K. C., Weber, P. S. and Weber, J. E. (2006). Scale and Study of Students Attitudes Toward Business Education's Role in Addressing Social Issues. Journal of Business Ethics, Vol. 68 No. 4, pp. 381-391.

Tafel, K., \& Alas, R. (2007). Various types of Estonian top-managers. Journal of Business Economics and Management, Vol. 8 No. 3, pp. 189-194.

Tafel-Viia, K., \& Alas, R. (2009). Differences and Conflicts between Owners and top Managers in the Context of Social Responsibility. Engineering Economics, Vol. 4, pp. 86-94.

Tanimoto, K., Suzuki, K. (2005). Corporate Social Responsibility in Japan: Analyzing the participation companies in global reporting initiative. Working Paper 208.

Ubius, U., and Alas, R. (2009), Organizational Culture Types as Predictors of Corporate Social Responsibility. Inzinerine Ekonomika-Engineering Economics. Vol. 1, No. 90-99.

Waddock, S., Graves, S. (1997). The corporate social performance-financial performance link. Strategic Management Journal, Vol. 18 No. 4, pp. 303-319.

Wood, D. J. (1991). Social Issues in Management: Theory and Research in Corporate Social Performance. Journal of Management, Vol. 17 No. 2, pp.383-406. 
Tables

Table 1. Facet of CSR - the firm performance concerning social issues in machine-building, electricelectronic machine and retail store enterprises

$\begin{array}{llll}\begin{array}{l}\text { Facet of CSR - the firm performance } \\ \text { concerning social issues }\end{array} & \begin{array}{l}\text { Machine- } \\ \text { building } \\ \text { industry }\end{array} & \begin{array}{l}\text { Electric- } \\ \text { electronic } \\ \text { machine } \\ \text { industry }\end{array} & \text { Retail store }\end{array}$

\begin{tabular}{|c|c|c|c|c|c|c|}
\hline & $\mathbf{M}$ & SD & $\mathbf{M}$ & SD & $\mathbf{M}$ & SD \\
\hline $\begin{array}{l}1-\text { compliance with the laws for business } \\
\text { activities }\end{array}$ & 3.88 & 0.94 & 4.14 & 0.86 & 4.04 & 0.98 \\
\hline $\begin{array}{l}2 \text { - compliance with the laws for worker } \\
\text { protection }\end{array}$ & 3.57 & 1.11 & 3.93 & 0.99 & 3.85 & 1.08 \\
\hline 3 - care and service for consumers & 3.53 & 1.07 & 3.86 & 0.85 & 4.12 & 0.89 \\
\hline 4 - environmental protection & 3.62 & 1.02 & 4.05 & 0.88 & 3.86 & 1.06 \\
\hline 5 - trustful relations with customers & 3.85 & 0.98 & 4.00 & 0.84 & 4.10 & 0.92 \\
\hline $\begin{array}{l}6 \text { - safety and security of products and } \\
\text { services }\end{array}$ & 3.86 & 0.95 & 4.08 & 0.87 & 4.21 & 0.86 \\
\hline $\begin{array}{l}7 \text { - realization of the best quality of } \\
\text { products and services }\end{array}$ & 3.93 & 0.96 & 4.16 & 0.84 & 4.17 & 0.88 \\
\hline 8 - aftercare for users & 3.78 & 0.99 & 3.84 & 0.89 & 4.06 & 0.96 \\
\hline $\begin{array}{l}9 \text { - publicity of company information for } \\
\text { society }\end{array}$ & 3.30 & 1.13 & 3.62 & 0.92 & 3.73 & 0.95 \\
\hline 10 - contribution to science and culture & 3.21 & 1.12 & 3.43 & 1.05 & 3.36 & 1.07 \\
\hline 11 - Public activities for local community & 3.17 & 1.14 & 3.29 & 1.04 & 3.43 & 1.06 \\
\hline Total & 3.60 & 1.03 & $\mathbf{3 . 8 5}$ & 0.92 & 3.90 & 0.97 \\
\hline
\end{tabular}


Table 2. Facet of CSR - the firm respect the interests of agents in machine-building, electric-electronic machine and retail store enterprises

\begin{tabular}{llll}
\hline Facet of CSR - The Firm Respect The & $\begin{array}{l}\text { Machine- } \\
\text { building } \\
\text { industry }\end{array}$ & $\begin{array}{l}\text { Electric- } \\
\text { electronic } \\
\text { machine } \\
\text { industry }\end{array}$ & Retail store \\
& &
\end{tabular}

\begin{tabular}{lllllll}
\hline & M & SD & M & SD & M & SD \\
1 - customers & 4.19 & 0.88 & 4.00 & 1.03 & 4.08 & 0.94 \\
\hline 2 - subsidiary, subcontract firms & 3.76 & 0.93 & 3.41 & 1.10 & 3.85 & 0.95 \\
\hline 3 - consumers; & 3.89 & 1.06 & 3.90 & 1.00 & 4.31 & 0.86 \\
\hline 4 - stock holders; & 3.63 & 1.18 & 3.97 & 0.91 & 3.37 & 1.16 \\
\hline 5 - employees & 3.34 & 1.04 & 3.09 & 1.13 & 3.59 & 1.15 \\
\hline 6 - trade union & 3.01 & 1.25 & 3.16 & 1.12 & 3.01 & 1.30 \\
\hline 7 - public administration & 3.39 & 1.00 & 3.41 & 0.93 & 3.27 & 1.30 \\
\hline 8 - local community & 3.28 & 1.04 & 3.28 & 1.05 & 3.36 & 1.33 \\
\hline Total & $\mathbf{3 . 5 6}$ & $\mathbf{1 . 0 5}$ & $\mathbf{3 . 5 3}$ & $\mathbf{1 . 0 3}$ & $\mathbf{3 . 6 0}$ & $\mathbf{1 . 1 4}$ \\
\hline
\end{tabular}

Tabel 3. The Firm Performance Concerning Social Issues in Estonia, China, Japan, Finland, Germany, Czech and Slovakia

\begin{tabular}{l|lllllllllllll}
\multicolumn{1}{l}{} & & $\mathbf{1}$ & $\mathbf{2}$ & $\mathbf{3}$ & $\mathbf{4}$ & $\mathbf{5}$ & $\mathbf{6}$ & $\mathbf{7}$ & $\mathbf{8}$ & $\mathbf{9}$ & $\mathbf{1 0}$ & $\mathbf{1 1}$ & SUM \\
\hline ESTONIA & M & 4.37 & 4.11 & 3.98 & 4.20 & 4.54 & 4.22 & 4.40 & 4.29 & 3.33 & 3.21 & 2.88 & $\mathbf{3 . 9 5}$ \\
N=623 & SD & 0.80 & 0.95 & 1.12 & 1.02 & 0.62 & 0.85 & 0.71 & 0.77 & 1.14 & 1.09 & 0.96 & $\mathbf{0 . 8 4}$ \\
CHINA & M & 4.11 & 3.96 & 4.15 & 4.11 & 4.20 & 4.36 & 4.38 & 4.30 & 4.11 & 3.99 & 4.06 & $\mathbf{4 . 1 5}$ \\
N=1150 & SD & 0.95 & 1.09 & 0.99 & 1.01 & 0.97 & 0.89 & 0.86 & 0.90 & 0.97 & 1.03 & 1.03 & $\mathbf{1 . 0 2}$ \\
JAPAN & M & 3.82 & 3.43 & 3.51 & 3.50 & 3.56 & 3.71 & 3.70 & 3.51 & 3.24 & 2.98 & 2.97 & $\mathbf{3 . 4 4}$ \\
N=1570 & SD & 0.91 & 1.06 & 0.83 & 0.89 & 0.81 & 0.84 & 0.89 & 0.87 & 0.85 & 0.92 & 0.93 & $\mathbf{0 . 8 9}$ \\
FINLAND & M & 3.99 & 4.18 & 3.58 & 3.59 & 4.02 & 4.14 & 4.16 & 3.34 & 3.22 & 2.75 & 2.89 & $\mathbf{3 . 6 2}$ \\
N=239 & SD & 0.96 & 0.95 & 0.88 & 0.94 & 0.93 & 0.92 & 0.87 & 0.86 & 0.90 & 0.84 & 0.82 & $\mathbf{0 . 9 1}$ \\
SLOVAKIA & M & 3.91 & 3.80 & 4.05 & 3.83 & 4.07 & 4.07 & 4.12 & 3.90 & 3.56 & 3.28 & 3.21 & $\mathbf{3 . 8 0}$ \\
N=605 & SD & $\mathbf{0 . 9 8}$ & $\mathbf{0 . 9 8}$ & $\mathbf{0 . 8 8}$ & $\mathbf{1 . 0 0}$ & $\mathbf{0 . 9 3}$ & $\mathbf{0 . 8 6}$ & $\mathbf{0 . 8 7}$ & $\mathbf{0 . 9 5}$ & $\mathbf{0 . 9 9}$ & $\mathbf{1 . 0 8}$ & $\mathbf{1 . 0 8}$ & $\mathbf{0 . 8 7}$
\end{tabular}

Notes: The firm performance concerning social issues: 1 - compliance with the laws for business activities; 2 - compliance with the laws for worker protection; 3 - care and service for consumers; 4 environmental protection; 5 - trustful relations with customers; 6 - safety and security of products and services; 7 - realization of the best quality of products and services; 8 - aftercare for users; 9 - publicity 
of company information for society; 10 - contribution to science and culture; 11 - public activities for local community.

Tabel 4. The firm respects the interests of agents in Estonia, China, Japan, Finland, Germany, Czech and Slovakia

\begin{tabular}{|c|c|c|c|c|c|c|c|c|c|c|}
\hline & & 1 & 2 & 3 & 4 & 5 & 6 & 7 & 8 & SUM \\
\hline ESTONIA & $\mathbf{M}$ & 4.26 & 3.51 & 3.83 & 2.91 & 3.54 & 2.42 & 2.76 & 2.64 & 3.23 \\
\hline $\mathrm{N}=623$ & SD & 1.21 & 1.38 & 1.33 & 1.35 & 1.41 & 1.40 & 1.28 & 1.36 & 1.26 \\
\hline CHINA & M & 4.28 & 4.07 & 4.33 & 3.85 & 3.69 & 3.69 & 3.98 & 3.96 & 3.98 \\
\hline $\mathrm{N}=1150$ & SD & 0.88 & 0.85 & 0.86 & 1.08 & 1.12 & 1.15 & 0.93 & 1.03 & 1.06 \\
\hline IAPAN & $\mathbf{M}$ & 3.74 & 3.41 & 3.88 & 3.44 & 3.06 & 3.03 & 3.19 & 3.13 & 3.82 \\
\hline $\mathrm{N}=1570$ & SD & 0.82 & 0.86 & 0.91 & 0.91 & 0.93 & 0.91 & 0.84 & 0.89 & 0.87 \\
\hline FINLAND & $\mathbf{M}$ & 4.44 & 3.02 & 3.69 & 4.19 & - & 2.45 & 2.68 & 2.77 & 3.32 \\
\hline $\mathrm{N}=239$ & SD & 0.98 & 1.10 & 1.12 & 0.96 & - & 0.98 & 0.90 & 0.95 & 0.96 \\
\hline SLOV & $\mathbf{M}$ & 4.10 & 3.81 & 3.95 & 4.15 & 3.30 & 3.37 & 3.69 & 3.66 & 3.75 \\
\hline $\mathrm{N}=605$ & SD & 0.91 & 0.85 & 0.90 & 0.93 & 1.06 & 1.08 & 0.98 & 0.98 & 0.97 \\
\hline
\end{tabular}

Notes: The firm respects the interests of the following agents: 1 - customers; 2 - subsidiary, subcontract firms; 3 - consumers; 4 - stock holders; 5 -employees; 6 - trade union; 7 - public administration; 8 - local community. 